\title{
PERANGKAT LUNAK
}

\author{
MINI TINJAUAN PEMAKAIAN MICROSOFT WORD SELAKU \\ PERANGKAT LUNAK PENGOLAH KATA
}

Putri Yolanda PMM FITK UINSU

\begin{abstract}
ABSRAK
Suatu komputer tidak hanya didasari dengan terdapatnya hardware ataupun perangkat keras, tetapi dalam suatu komputer wajib pula dilengkapi dengan fitur yang bisa mencerna kata ataupun angka dalam pemakaian komputer, fitur pengolah angka ataupun pengolah kata tersebut dinamakan perangkat lunak. Tetapi perangkat lunak pengolah kata tidak cuma sebatas kita dapat mengetik suatu kata ataupun menginput suatu kata dari suatu komputer. Dalam penelitian ini, penelliti mengkaji apa saja yang bisa kita jalani dengan perangkat lunak pengolah kata dalam komputer, apakah hanya sebagai tempat buat kita menginput kata ataupun yang lain. Tujuan dibuatnya studi ini yakni supaya kita semua mengetahui apa aku yang dapat kita jalani dengan terdapatnya sistm pengolah kata ini, ataupun selalu pula kita sebut Microsoft word. Hasilnya menunjuukan kalau banyak yang bisa kita jalani dengan memakai Microsoft word, serta tidak cuma bisa menginput suatu kata yang perintahnya di sampaikan melalui keyboard dalam perangkat keras, namun Microsoft word juga bisa menolong kita dalam bermacam perihal serta tidak cuma senantiasa tentang pengolahan kata saja. Namun sesudah di adakannya studi ini, diharapkan pengguna komputer bisa lebih mengerti serta lebih mengenali pemakaian Microsoft word dalam sistem operasi komputer.
\end{abstract}

Kata kunci $\quad$ : micrososft word, komputer, perangkat lunak, pengolah kata 


\section{A. Pendahuluan}

Di kehidupan kita saat ini ini, dunia teknologi telah tumbuh pesat serta memberikan akibat yang bisa pengaruhi pertumbuhan sistem informasi dalam pembelajaran kita dikala ini. Serta dengan berkembangnya dunia teknologi pada disaat ini nyatanya itu memunculkan perihal baru yang lumayan menarik buat dikenal.

Teknologi informasi serta komunikasi itu sanggup menciptakan teknologi yang unggul yang bisa berfungsi bernilai dalam pemrosesan manipulasi pengelolaan transfer informasi antar fitur itu pula dialami nyaris di segala aspek kehidupan tercantum dalam aspek pendidikan

Sistem informasi pula bakal terus tumbuh bersamaan dengan terdapatnya pertumbuhan dunia teknologi untuk penuhi kebutuhan penggunanya. Dengan terdapatnya kemajuan teknologi ini, hingga komputer yang notabenenya selaku fasilitas pengolahan data jadi informasi setelah itu diolah serta dibesarkan sedemikian rupa dalam penyajiannya, sehingga itu bakal mempermudah untuk para pengguna buat menyajikan data buat lembaga pembelajaran yang kerap hadapi pergantian dalam penyajian informasi

Dengan tumbuh pesatnya teknologi pada dikala ini, dunia sistem informasi pula ada banyak model sistem informasi yang mempunyai tujuan yakni bisa membagikan bermacam ragam data. Menurut( Langer, 2008), perangkat lunak ialah abstraksi fisik yang membolehkan kita buat berdiskusi dengan mesin perangkat keras. Tanpa adanya perangkat lunak, maka perangkat keras yang sudah diciptakan untuk memaksimalkan suatu sistem pc tidak bisa bermanfaat ataupun berperan secara optimal

Sebaliknya bagi( Al Fatah 2007), sistem ialah kumpulan dari bagian- bagian yang bekerja sama untuk menggapai tujuan yang sama, ataupun bisa pula dimaksud sistem ialah sesuatu kumpulan himpunan variabel- variabel ataupun sesuatu faktor yang saling berhubungan saling ketergantungan serta saling terorganisir supaya bisa memaksimalkan tujuan utamanya 
Menurut (kusrini 2007) informasi bisa diartikan data yang telah diolah jadi suatu wujud yang berarti untuk pengguna yang berguna dalam pengambilan keputusan dikala ini ataupun menunjang sumber sistem informasi. Informasi telah bernilai sebaliknya data belum bernilai. suatu informasi telah dikatakan mempunyai nilai bila manfaat dari informasi itu lebih besar dibanding anggaran buat mendapatkannya Menurut( oz 2009) sistem informasi itu terdiri dari seluruh komponen yang bekerja sama buat mencerna data serta prosedur informasi.

Sedangkan menurut( Stair 2016) komponen sistem informasi itu terdiri dari unsurunsur semacam masukan ataupun input pengolahan ataupun processing keluaran ataupun output dan umpan balik ataupun feedback. Komponen- komponen yang terdapat dalam suatu sistem informasi berbasis komputer ialah dibagi atas perangkat lunak ataupun software perangkat keras ataupun hardware prosedur ataupun prosedures orang ataupun people basis data ataupun database serta jaringan komputer ataupun computer network

Menurut( Situmorang 2010) dalam webster new world dictionary mengatakan jika informasi merupakan think known or assumed, yang berarti bahwa informasi itu merupakan suatu yang dikenal ataupun diduga. Data pula bisa dimaksud selaku sekumpulan informasi ataupun nilai yang diperoleh dari pengamatan sesuatu objek serta data itu bisa berbentuk angka kata lambang ataupun sifat. Sehingga dari itu kita bisa kita definisikan kalau data bisa membagikan cerminan tentang sesuatu kondisi ataupun perkara.

Perangkat lunak sendiri ialah sebutan spesial untuk informasi yang dikemas serta di format secara digital yang dokumentasinya serta bermacam informasi yang bisa dibaca dan di tulis oleh komputer. Ataupun dapat pula kita sebut, bahawa perangkat lunak merupakan bagian dari sistem komputer yang tidak berwujud. Perangkat lunak sendiri terdiri dari sebagian sistem pengolahan, semacam pengolahan angka, pengolahan kata, pengolahan data, pengolah presentasi, 
pengolah gambar, pengolah audio serta video, pengolah web, pengolah bisnis serta keuangan.

Perangkat lunak juga ialah suatu sekumpulan program yang dilengkapi dengan terdapatnya dokumentasi yang berhubungan secara langsung dengan komputer perangkat lunak pula digunakan buat melaksanakan fungsi- fungsi yang di idamkan ataupun dapat pula kita sebut kumpulan instruksi- instruksi dalam suatu komputer seperti memanajemen data pembuatan dokumentasi ataupun inventarisasi serta pengembangan yakni erat sekali hubungannya dengan pengembangan sistem operasi serta pengaplikasiannya yang bakal dijalankan. Dari sisi aplikasinya, perangkat lunak dibedakan jadi 3 yakni personal packaged software yakni merupakan sekumpulan perangkat lunak yang sudah diintegrasikan dengan terencana pada perangkat keras dalam perihal ini komputer bertujuan mempunyai kepentingan yang sifatnya personal. Personal word software mempunyai bagian yang dinamakan word processor. Word processor ialah bagian yang mencakup tugas totalitas dari sesuatu perangkat lunak pengolah kata yang didasari dengan peranan memperbolehkan sang pengguna untuk membuat dokumentasi berbentuk bacaan serta yang tercantum dalam kategori itu merupakan novell' s, Microsoft word for Windows dan wordperfect for Windows.

Yang kedua terdapat wordgrup computing itu ialah perangkat lunak yang mempunyai peranan kerja sama dalam area kerja. Dataquest dapat menelusuri serta memberi tahu 7 jenis utama dalam perangkat lunak komputasi workgroup. Yang ketiga ialah enterprise application, enterprise application ialah serangkaian aplikasi yang di desain untuk menolong para pengguna dalam perihal pengelolaan data serta menunjang fungsi- fungsi bisnis dari sesuatu organisasi. Aplikasiaplikasi yang berskala enterprise memakai campuran dari transaksi serta sistem pengolahan database. Dikala ini, ada sebagian paket aplikasi enterprise yang berbasis client ataupun server dari bermacam vendor perangkat lunak, ialah oracle, SAP, peoplesoft, serta Dun\&amp; brandsreet. 
Salah satu bagian dari perangkat lunak ialah perangkat lunak pengolah kata perangkat lunak pengolah kata ataupun dapat pula kita sebut Microsoft word. Microsoft word pada biasanya berisi tentang penerbitan suatu desktop yang belum sempurna serta Microsoft word pula ialah suatu program pengolah kata yang banyak digunakan oleh para pengguna komputer. File yang terdapat di word biasanya digunakan sebagai format buat mengirim dokumen berupa bacaan lewat email. Sebab pada biasanya file berupa word cuma dapat dibaca lewat aplikasi Microsoft word oleh para pengguna komputer.

Word processor ataupun yang kerap kita sebut pengolah kata adalah salah satu aplikasi pendukung yang bisa digunakan buat mencerna informasi yang umumnya disajikan dalam wujud bacaan. Menurut Wikipedia" A word processor( also more formally known as a document preparation system) is a computer application used for the production( including composition, editing, formatting, and possibly printing) of any sort of viewable or printed material”.

kerapkali kita memakai program pengolah kata atau dapat pula kita sebut Microsoft word dengan sarana sarana yang terdapat hanya untuk menolong kita mengetik serta membuat postingan saja tetapi tidak seluruh sarana itu digunakan buat pengetikan apalagi banyak juga sarana lain yang tidak digunakan sama sekali sehingga pemanfaatan aplikasi Microsoft word itu menimbulkan ketidak efektifan. Mayoritas aplikasi pengolah kata dikala ini telah ada fitur fitur yang bisa menolong pengguna merasa nyaman.

\section{B. Studi Literatur}

Pengamatan tentang pemakaian Microsoft Word selaku perangkat lunak pengolah kata, ialah sesuatu perihal yang bisa dicoba untuk mengenali apa saja yang bisa dicoba dengan Microsoft word selaku perangkat lunak pengolah kata.

Mekanisme yang dicoba dalam riset ini yakni dengan mengkaji serta mencari tau tentang Microsoft Word dengan melaksanakan studi pustaka, pengamat melaksanakan kajian dengan mencari sebagian sumber mengenai micrososft word 
serta pemakaian, guna dan apa saja yang bisa dicoba dengan Microsoft word selaku perangkat lunak pengolah kata.

C. Metode Penelitian

Secara totalitas, dalam studi ini memakai metode yang dicoba dengan sebagian langkah semacam melaksanakan studi pustaka dengan mencari sebagian sumber yang mangulas tentang pemakaian microssoft word selaku perangkat lunak pengolah kata, yang kedua ialah pengumpulan data, yakni mengumpulkan informasi informasi berarti dari hasil kajian pustaka tadi serta yang terakhir pengumpulan fakta yakni pengambilan hasil dari studi pustaka serta pengumpulan informasi yang telah dicoba tadinya.

\section{Pembahasan}

Microsoft office ataupun yang biasa kita sebut office ialah keluarga dari perangkat lunak yang dibesarkan oleh Microsoft serta awal kali diumumkan oleh pemiliknya bill gates pada 1 Agustus 1988 di komdes di las Vegas pada awal mulanya pemasaran untuk office ini tipe awal office berisi Microsoft word Microsoft Excel serta Microsoft PowerPoint tetapi sepanjang bertahun- tahun aplikasi office sudah berkembang jauh lebih pesat dengan fitur bersama pemeriksa ejaan umum biasanya microsoft pula memposisikan office selaku platform pengembangan untuk perangkat lunak bisnis di bawah merek aplikasi bisnis office pedia memberi tahu kalau office digunakan lebih dari satu miliyar orang di seluruh dunia pada tahun 10 Juli 2012 Microsoft word buat sistem operasi Windows telah ada secara sendiri ataupun sebagai bagian dari Microsoft office, Microsoft word memiliki\&nbsp; keahlian penerbitan desktop yang belum sempurna serta merupakan program yang yang berisi pengolah kata yang sangat banyak digunakan di pasaran ataupun oleh para pengguna komputer.

Microsoft word ialah perangkat lunak ataupun suatu program aplikasi pengolah data yang berbentuk huruf ataupun angka serta bisa dipergunakan untuk keperluan 
pekerjaan bisnis pembuatan laporan dokumen makalah skripsi serta lainnya dan dibesarkan oleh industri Microsoft.

Microsoft word sendiri ialah produk andalan dari Microsoft yang sangat banyak digunakan oleh kebanyakan pengguna komputer ataupun laptop di dunia. Dengan terdapatnya Microsoft word, bisa memberikan banyak transformasi pada masa digital yang terdapat disaat ini. Dengan Microsoft word pula, bisa mempermudah kerja manusia buat melaksanakan pengetikan ataupun membuat dokumen.

Microsoft word awal kali dirilis pada 25 Oktober 1983 oleh IBM PC. Microsoft word ialah program yang awal kali bisa menunjukkan cetak tebal serta cetak miring pada IBM PC pada saat itu dunia pengolah kata dikuasai serta pula sangat digemari oleh wordstar serta word perfect. Pada tahun 1987 word tipe for machintos word 30 dirilis yang sebagian besar fiturnya mempunyai banyak kendala ataupun bug. Beberapa bulan sesudah itu Microsoft mengubah tipe nya jadi word 31 yang lebih stabil

Tidak hanya itu, pada tahun 1989 Microsoft merilis word 40 serta jadi tipe yang sangat sukses sebab tingkatan kestabilannya, serta pada tahun ini Microsoft juga merambah sistem operasi Windows serta merilis word for Windows dengan patokan harga senilai $\$ 500$. Pada tahun berikutnya produk penjualan word ini terus bertambah sampai pada kesimpulannya Microsoft mulai merajai dunia pengolah kata serta sampai pada saat ini tipe terkini dari word ini merupakan Microsoft word 2013 yang mengambil alih tipe tadinya yakni Microsoft word 2007 serta 2010.

Tampilan pada Microsoft word 2013 juga terkesan lebih elok serta lebih baik dengan perkembangannya itu Microsoft sudah meningkatkan database serta tools yang baru supaya dapat menyempurnakan Microsoft word lebih gampang digunakan oleh para pengguna. 
Bagian- bagian dari Microsoft word serta fungsinya

\section{Title Bar}

Title bar ialah bagian yang diberi ciri kotak merah dan merupakan judul ataupun nama dokumen yang lagi kita buka.\&nbsp; bila kita belum menyimpan dokumen itu maka dokumen tersebut akan tertulis dokumen, bila kita telah menyimpan dokumen tersebut maka dokumen tersebut akan tertulis nama file yang telah kita simpan

\section{Quick Access Toolbar}

Quick access toolbar bisa pula kita katakan sebagai akses cepat. sebab terkadang pada saat kita mau melaksanakan sesuatu perintah tertentu kita wajib lewat 2 ataupun 3 kali klik menu oleh karna itu sarana ini dibuat untuk mempermudah akses sebab dengan sekali akses kita dapat melaksanakan perintah yang kita mau baik access toolbar ini dapat kita tambah serta kita mengurangi sesuai dengan kemauan kita

\section{Tab Menu}

Tab menu merupakan masing- masing menu yang mempunyai turunan menu yang banyak dapat kita amati pada pada menu home misalnya ada kurang lebih 6 kelompok menu serta di dalam tiap- tiap menu tersebut ada ikon menu yang lebih banyak lagi

\section{Ribbon Menu}

Ribbon menu ialah turunan menu ataupun turunan kelompok dari menu yang terdapat di tab menu tadi. Ribbon menu itu berisi banyak menu yang dapat kita akses langsung serta berisi perintah- perintah untuk mengendalikan tipe huruf warna huruf dan sebagainya

\section{Office Button}


Office button ialah suatu tombol yang berlogo Microsoft office serta berisi menumenu eksekusi finish untuk menyimpan dokumen mencetak serta dapat pula membuka lembar kerja baru.

\section{Lembar Kerja}

lembar kerja merupakan sesuatu halaman yang bisa berperan buat tempat kita menulis merangkai perkata serta membuat suatu dengan kebutuhan dan keperluan tiap- tiap lembar kerja inilah kita bisa bekerja serta mengerjakan suatu amati di dasar ada penjelasan jumlah kata nomor halaman serta pula bahasa yang digunakan dalam penyusunan pada bagian kiri dan atas juga ada ruler dan atau skala

\section{Scrollbar dan Zoom}

Scroll bar ialah salah satu bagian dari Microsoft word yang berperan buat menaikkan serta merendahkan halaman kerja yang kita buat pada saat kita tengah mengarah pada halaman awal ataupun halaman berikutnya serta dalam scroll bar itu ada menu pengaturan tampilan yang terletak di sebelah zoom

\section{Home Menu}

Home menu pada software yang terdapat pada Microsoft word terletak bagian pojok kiri atas dengan tulisan home. Dalam form menu ada icon icon menu yang terdapat pada home menu, seperti

clipboard, yang ialah bentuk perintah- perintah semacam copy paste cut format painter serta kita dapat memakai menu ini pada saat kita mau mengcopy paste memotong suatu kata ataupun kalimat dalam lembar kerja kita pada Microsoft word yang lagi kita kerjakan

Font, yaitu suatu menu di mana kita bisa mengendalikan tipe huruf bentuk huruf warna huruf serta yang berhubungan dengan huruf

Paragraf, pada menu ini lumayan kompleks tetapi tidak seluruhnya dapat kita gunakan namun pada menu yang satu ini nyaris seluruhnya kita pakai sebab pada 
menu ini berisi tentang pengaturan paragraf membuat rata kanan serta kiri serta berikan no serta membuat bullet serta sebagainya pada kalimat ataupun kata di lembar kerja kita

Styles, pada menu ini kita dapat melihat beberapa gaya untuk mengendalikan secara mudah gaya metode penyusunan yang mau kita pakai tanpa harus satu persatu

\section{Insert Menu}

Hampir sama dengan menu home insert menu pada Microsoft word juga mempunyai banyak sekali anak menu yang mempunyai peranan masing- masing ialah menyisipkan ataupun memasukkan objek ke dalam lembar kerja buat lebih jelasnya kita bahas satu persatu

Page insert, page ialah suatu menu untuk menambahkan halaman baru setelah itu memberi cover halaman serta juga bisa mengendalikan ataupun menimbulkan tampilan page break

Tables and illustrations, Pada bagian ini sesungguhnya dibagi jadi 2 ialah tables serta illustration. menu tables berperan untuk membuat insert table pada lembar kerja yang lagi kita kerjakan sebaliknya menu illustration berperan untuk memasukkan suatu foto ataupun picture yang mau kita tambahkan dalam lembar kerja kita

Header and footer, pada Microsoft word digunakan buat menambahkan suatu nomor pada sesuatu halaman di lembar kerja kita baik itu nomor di atas serta pula nomor di bawah halaman

Teks, pada bagian teks ini kita dapat membuat text box quick parts word art drop cap serta membuat signature Line menyisipkan data serta waktu serta pula objek Simbol, pada menu ini kita bisa menyisipkan simbol simbol yang terdapat pada menu simbol dalam lembar kerja yang lagi kita kerjakan dengan mudah 
Page layout menu, ini berperan buat membagikan pengaturan melalui lembar kerja kita, pada menu ini kita dapat memandang menu lain semacam page layout, term, background, paragraf serta pula pengatur layout gambar Page setupe, ialah salah satu menu yang kerap digunakan serta nyaris kita pakai pada dikala kita mau membuat laporan pekerjaan di Microsoft word kita senantiasa memakai menu ini sebab pada menu ini kita dapat mensetting margin tulisan yakni mensetting ukuran kertas rata kanan serta rata kirinya Paragraph, pada menu ini kita pula dapat mengendalikan spasi antar paragraf antarkalimat serta pula mengendalikan indent dengan ukuran yang dapat kita tentukan sendiri

. Microsoft word pula memiliki manfaat serta peranan yaitu

- Satu untuk membuat file ataupun dokumen dengan cepat serta tepat

- Dua untuk membuat dokumen dengan cepat serta pas dan dengan ragam tulisan yang lebih menarik

- Tiga untuk membuat tulisan menyurat dalam urusan formal maupun

- Empat untuk membuat keperluan tipografi penyusunan serta mempersiapkan dokumen dalam format tertentu dengan ukuran besar ataupun kecil Microsoft word memiliki sekian banyak manfaat antara lain adalah

- Dapat memudahkan pekerjaan dalam urusan administrasi serta pengolahan kata

- Menghemat tenaga serta waktu

- Menghemat bayaran serta menghemat kertas

- Dapat meminimalisir tingkatan kesalahan dalam penulisan

- Dapat mempercepat penyelesaian kerja sebab lebih efisien

Karna digunakan untuk membuat dokumen kata, maka dari itu Microsoft word ini juga mempunyai peranan yang lebih menjurus pada pembuatan novel. Oleh karna 
itu, banyak peranan yang dipunyai Microsoft word ini bisa mempermudah seseorang penerbit maupun penulis buat menerbitkan hasil karyanya

\section{A. Kesimpulan}

Sudah disebutkan di atas bahwa, Microsoft word memiliki bagian bagian yang masing masing memiliki fungsi dan tujuan yang berbeda manfaatnya dalam lembar kerja yang kita buat dalam Microsoft word. Sebagai salah satu perangkat lunak pengolah kata, Microsoft word tidak hanya berfungsi sebagai tempat untuk kita membuat sebuah lembar kerja sepereti dokumen yang berbentuk kata saja, namun ada serimu manfaaat yang bisa klita dapatkan atau lebih jelasnya lagi kita bisa menggunakan Microsoft word bukan hanya sebatas untuk membuat sebuah dokumen lembar kerja saja, namun kita bisa mengunakan microsotf word untuk membuat sebuah document yang berisi gambar dan lainnya dengan catatan kita tau dan paham mbagaimaa cara memksimalkannya.

Dalam Microsoft word ini, kita juga bisa menggunakan kombinasi tombol=tombol yang ada di keyboard untuk melakukan sebuah perintah pada lembar kerja yang sedang kita buat di Microsoft word, seperti kita dapat mengkombinasikan tombol ctrl+c untuk mengcopy sebuah tekx dari sumber lain untuk di tambahkan ke lembar kerja kita dan dengan menekan tombol ctrl+v kita bisa mempaste teks tersebut kedalam lembar kerja kita di Microsoft word. 
A. Daftar Pustaka

Maulana, Yana Iqbal. (2017). Perancangan Perangkat Lunak Sistem Informasi Pendataan Guru Dan Sekolah (Sindaru) Pada Dinas Pendidikan Kota Tanggerang Selatan. Jurnal Pilar Nusa Mandiri, Vol 13, No 1, 2527 - 6514.

Prabandari, Rosiana. Fitiani, Aida. and Sari Rafika. (2020). Optimalisasi Penggunaan MS. Word dan MS Excel Pada Siswa SMP PGRI Astra Insani Bekasi. Jurnal ABDIMAS (Pengabdian Kepada Masyarakat) UBJ, Vol 3, No 2, 2614 - 2201, hal $95-104$.

Syakti, Firamon. (2019). Metode Pengembangan Perangkat Lunak Berbasis Mobile: A Riview. Jurnal Bina Komputer, Vol 1, No 2.

Mandala, Rila. Paseru, Debby. Tumewu, Alfonso Mario. (2007). Pembuatan Aplikasi Pengolah Kata Sederhana. Seminar Nasional Aplikasi Teknologi Informasi, $1907-5022$

Nadlifatin, Reny. Febriana R, Aisyah. Hendria P, Annisa. (2019). Bamoe Edukasi Untuk Sekolah Al-Qorrobiyah Desa Sendang Dajah. Jurnal Abdikarya: Jurnal Karya Pengabdian Dossen dan Mahasiswa,, Vol 03, No 04, 2655 - 9706.

Nur Aisyah, Mimin. (2013). Tingkat Penguasaan dan Penggunaan ICT (Information And Communication Technology) Pada Mahasiswa Akuntansi Universitas Negeri Yogyakarta. Jurnal Nominal. Vol 2, No 1.

Rosyidah, Masayu. Marhaini. Kartika Sary, Reny. Ardianto, Febi. Apriani, Yosi. (2016). Pelatihan Penggunaan Microsoft Office bagi Guru SMP Al-Hamididiyah Palembang. Jurnal Abdimas Madani dan Lestari, Vol 01, No 01, 2477 - 0574.

Vertuoso, Aan. (2010). Mahir MS Word 2007. Yogyakarta: Pustaka Grhatama.. Kusrianto, Adi. (2008). Shortcut-Shortcut Unggulan Micrisoft Office, Word, dan PowerPoint 2007. Jakarta:PT Alex Media Komputindo. 


\section{BIODATA DIRI}

PUTRI YOLANDA saat ini sebagai mahasiswi aktif pada program studi S-1

Pendidikan Matematika, Fakultas Ilmu Tarbiyah dan Keguruan Universitas Islam Negeri Sumatera Utara 